\title{
発想支援のための作図システムの構築
}

\section{Drawing System for Idea Creation Support}

\author{
村川猛彦草, 牧野茂一1 \\ Takehiko MURAKAWA ${ }^{1 *}$, Shigekazu MAKINO ${ }^{1}$
}

\section{1 和歌山大学}

Wakayama University

₹640-8314 和歌山市栄谷930

E-mail: takehiko@sys.wakayama-u.ac.jp

*連絡先著者 Corresponding Author

アイデア創出の過程において, 人間の持つ情報や知識をコンピュータに保持し, 可視化すること で, 情報どうしのつながりを明確にすると同時に, デザイン対象の全体像をつかみやすくなる. 本研 究では, 多空間のデザイン思考を支援するMメソッドに焦点を当て, その空間を考慮してScalable Vector Graphics画像による図を生成するシステムを試作した. 図に記載される情報が木構造をなす 点に注意してデータ構造を定義し, 各情報が配置される領域を再帰的な手続きにより算出するよう にした.

During idea creation, storing information and knowledge into a computer for visualization makes clear the relationship among pieces of information and enables us to get the whole story of the design. In this research, we focused on M Method which supports a multispace design process, and developed the prototypes of generating Scalable Vector Graphics images that represent M Method charts. We defined the data structure in consideration of the fact that such a chart has a tree structure under the containment relationships, and the prototypes compute the coordinates of rectangular regions in a recursive way.

キーワード：情報の表現, 作図, SVG, 発想支援

information representation, drawing, Scalable Vector Graphics, creativity support

1 はじめに

現在, 自動車やスマートフォンなど高機能 な製品が広く普及してきている．また，情報
化社会のもとでソーシャルネットワークサ ービス(SNS)をはじめとする様々なサービス も利用されている.「モノづくり」において も「コトづくり」においても，時代の流れに 
応じて常に進化と変化を繰り返してきた.

新たな製品やサービスの源となるアイデ アについて,アルゴリズムなどによる自動生 成は未だ困難であり, 計算機によるデータ管 理や整形表示を活用しつつ, 人の手によって 生み出されているのが現状である.しかし， 画期的な発想・アイデアを生み出すのは容易 ではない. アイデア創出の過程で綿密な想定 をしておかないと, 製造・実装時に判明する 追加コストや, 販売・運用後に生じる想定外 の出来事により, 思うように行かない場合も 起こり得る. そのため, 目的に応じて, 適切 な既存の発想技法を採用するか, 良いものが なければ自ら開発する必要があった。

これまで様々な分野において, 人々がアイ デアを生み出すための方法として発想技法 が提案され, 活用されてきた. その中には, 発想技法や表現形態に応じた支援方法 (支援 ソフトウェアの開発など）も見受けられる. 近年,「自由な思考」と「理にかなった思考」 を両立した発想技法であるMメソッド[1]が 考案され, 製品設計やシステムデザインへの 適用が試みられている.

本研究では, Mメソッドの図を描画するシ ステムを開発した[2]. データベースに格納 されたデータ, またはインデント化されたテ キストデータを入力にとり, 図をScalable Vector Graphics (SVG)画像として生成する. 画像はブラウザを用いて表示可能である. 紙 媒体を必要とせず, 作図するための負担が小 さい点が特長として挙げられる.

\section{2 準備}

\section{1 発想支援}

発想とは物事に対する考えであり, 把握や, 見解, 思いつきや理解などが含まれる. ふだ
ん我々はあらゆる場面で考える. その「考え るという行為」をより創造的にする試みが, 発想支援である. そのための手立てを用意す ることによって，「考えるという行為」を創 造的にすることが可能となる. また, その手 立てをルールとして体系的に記述し学びや すくしたものが発想技法であり，技法を物理 的に体現する道具を発想支援システムと呼 ぶ. 発想支援システムを利用することによっ て, 利用者はルールを意識的に実行しなくて もおおむねその技法に則った考え方をする ことになる.

発想支援技法の代表的な例として川喜田 二郎によるKJ法, ブザンによるマインドマッ プ, 烟村洋太郎らによる思考展開図などがあ る. 筆者らの研究室ではこれまで, 思考展開 図を対象とした描画システムを開発し, デー タベースの問い合わせ（SQL文）に適用する ことを試みてきた[3][4][5].

\subsection{Mメソッド}

Mメソッド[1][2]は多空間デザイン法とも 呼ばれる. 多空間を視点とすることで, 整理 しやすく, 自分の好きなやり方で自由に使え ることを意図している. デザイン作業にあた っては, 分析しながら発想を行い, デザイン 要素を抽出し,「分類」「構造化」「分解と 追加」をすることで, 従来では難しかった「自 由な思考」と「理にかなった思考」の両立を 実現する新しい思考メソッドである. プロダ クトデザインはもとより, 様々な分野におけ る活用での応用が期待されている.

本稿ではMメソッドで作成される, 一定の 様式を持った図を「Mメソッド図」と呼ぶ. Mメソッド図は「価值」「意味」「状態」「属 性」「場」の5つの空間で構成されており, 各 空間は長方形として描かれる.「場」を除く 
4つを，順に上から下になるよう階層的に配 置し,「場」はそれらの右に, 縦長の長方形 として配置する. 各空間について[1]では, 価 值は「文化的価值や機能的価值」, 意味は「機 能性やイメージ」, 状態は「モノと場の関係」, 属性は「モノの形や形状」を, 代表例として それぞれ挙げている.

各空間には, 囲い込まれた領域があり，原 則として各領域にはラベルが記されている. また各領域はその中に領域を持つことがで き，本稿ではそれを「子領域」と呼ぶ．包含 関係に注目すると, 一つの図に記載される情 報は, 木構造をなす. 図全体を根とし, それ ぞれの空間および領域が節点に対応する. そ して空間・領域における, 要素間の包含関係 が，木の親子関係となる.

作成者は, その空間ごとに当てはまると思 った各情報をラベル化し, 空間の位置や情報 間の親子関係に注意して, 図内にデザイン要 素として自由に配置していく. 異なる空間に ある領域どうしを，直線または折れ線で結び， 関連性を示すこともできる. 最初から各空間 に詳しく情報を記載する必要はなく, 初期段 階では各空間への主要な要素を記載し, 検討 を通じて詳細化・構造化してもよい. 多空間 の視点でデザイン要素を分割し, それらの関 係を図に乗せることで, デザイン対象全体を 分析し, デザイン思考の客観化[6]を行うこ とができる.

\section{3 既存のMメソッド図の分析}

[1]に掲載されているMメソッド図につい て概要を述べる. 同書では, 実践編において アイウェア (眼鏡) , ワークデスク, USBメ モリ, ビークル（乗り物）, そしてモビリテ イについて検討がなされ, それぞれ途中段階 および最終段階のMメソッド図が見られる.
このうちモビリティがコトづくりに, 残り 4 つがモノづくりに関するデザインである.

各デザインについて最終段階の Mメソッ ド図を対象とし, 図中の英語併記は無視して, ラベルの数などを集計したところ表1のよう になった.「深さ」とは, 図全体を木とした ときの, 包含関係が最も深い領域の包含の重 複数である. 各空間に子領域のない領域のみ の場合は 3 としている. 深さが5というのは, ある空間の領域が子領域を持ち, 子領域が子 領域を持ち, その次には子領域を持たないこ とを意味する.

モノづくりの4つの図において，価値の空 間は「機能価値」と「感性価値」という2つの 領域からなるなどの共通点も見られた. また コトづくりであるモビリティは, 各ラベルの 字数が大きくなりやすい (2〜3文字で表現し づらい情報がある）ことが確認できた.

\section{3 作図システムの開発}

\section{1 システム概略}

開発した作図システムには, PHP版とRuby 版の $2 つ$ づージョンがある. 最初はPHPで 作成し, ラベルおよび各領域の所属する空間 や領域間の包含関係を, データベース管理シ ステム(DBMS)に格納しておいたデータベー スより読み出し, 図を作成していた[2]. その 後, 拡張性や保守性を意図してRubyで全面 的に書き換えた. 入力は, 前述のデータベー スだけでなく, テキストデータからも獲得で きるようにした. テキストデータは各行が一 つの情報（図全体の名称, 空間名, または領 域のラベル）を表し, 親子関係をインデント で表現する. PHP版とRuby版の共通点には次 の2つがある. (1)出力はSVG画像であり，プ ログラムはXML文書を生成する，利用者は 
Internet Explorer, Mozilla Firefox, Google Chrome, Operaなど, SVGに対応するブラウ ザを用いてページを閲覧すればよい. (2)各 領域の座標情報（左上のXY座標, 幅および 高さ）は入力で指定せず, 入力内容に応じて プログラム内で算出している.

\section{2 データ構造}

配置において, 図全体, 各空間および各領 域はそれぞれ長方形の形状を持つ（ただし， [1]の図では領域を角丸長方形で描画してい る）点が指摘できる. そこでRuby版において は, 描画単位に関するクラス(「描画クラス」 と呼ぶ）を用意し, 図全体, 空間および領域 が, そのサブクラスとなるよう, データ構造 を定めた. 描画対象どうしの包含関係をhasa関係により保持する. これにより, 各イン スタンスのメンバへの值の設定や次節で述 ベる領域の算出などが, 再帰的なメソッドを 定義することで効率良く記述できる.

描画クラスには, 複数の子領域の配置に関 する特別なメンバを持つ. そのメンバに格納 される值は, :down, :right, :down_right, :right_down（先頭のコロンは, Rubyのシンボ ル表記を表す) のいずれかであり, それぞれ 「下方向に配置する」「右方向に配置する」 「直下は下方向に配置し, その子は右方向に 配置する」「直下は右方向に配置し, その子 は下方向に配置する」を意味する. 深い包含 関係があるとき，:down_rightと:right_downを 交互に適用すれば, 下方向や右方向に過度に 大きくなることが抑制される. Mメソッド図 の作成にあたっては, 場を除く各空間 は:right_down, 場は:down(縦長に配置される ため), 空間の直下の各領域は:down_rightと している.

\section{3 領域の算出}

ある領域およびその各子領域の座標情報 などを求めるために定義したRubyのメソッ ドについてその概略を述べる.

算出に使用する長さを図1に示す.この例 では, 領域のラベルを「ロ $\mathbf{\square} \boldsymbol{\square} \mathbf{\square}$ の2行

（入力行に”和”を書くか，1行の最大字数を 指定して別途定義したメソッドを呼び出す ことで, 行分割がなされる）とし, 子領域は

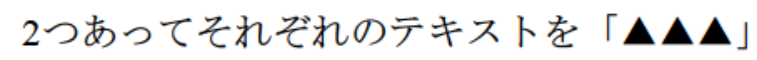

および「○○○」としている. また前節で 述べた複数の子領域の配置に関しては, その 値を:downとする.

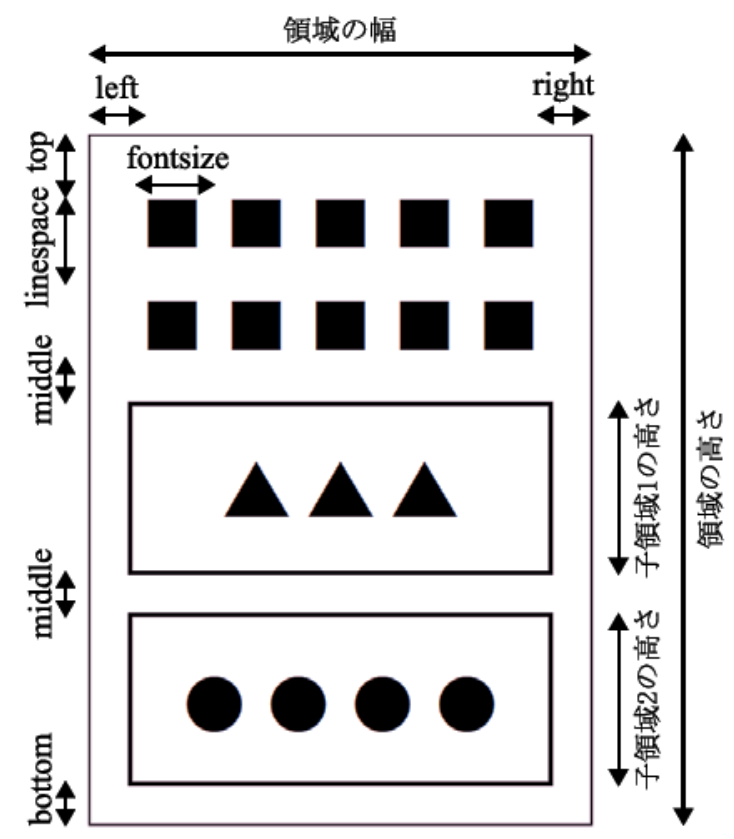

図1 領域算出に使用する長さ

このとき, 領域の幅は, left + max W + right により求められる.ここでWは, 領域のラべ ルに関する幅（fontsizeに, ラベルの文字数 (複数行にわたるときはその最大字数)を掛 けた值) および各子領域の幅からなる集合を 表し, max Wはその最大值である. 領域の高 さは, top + linespace $\times$ ラベルの行数 $+\Sigma \mathrm{H}_{\mathrm{i}}+$ middle $\times$ 子領域の数 + bottomにより求められ 
る. $\Sigma \mathrm{H}_{\mathrm{i}}$ は子領域の高さの総和を表す. 配置 の值が:down_rightの場合も同じである. :right または:right_downの場合や, 領域のラベルが ない場合などについても配慮し, 領域の幅お よび高さを求めるよう実装した.

領域算出のメソッドは, 次の順に処理を行 う. (1)再帰呼び出しを用いて, 各子領域の幅 と高さを求める. ただしこの段階では, 各子 領域の左上座標は $(0,0)$ である. (2)領域の幅と 高さを決定する. (3)各子領域が, 領域の子と して適切に配置されるよう, 幅を $\max \mathrm{W}$ 変 更してから，左上座標を設定する.

メソッド処理の終了時点では, 領域の左上 座標は $(0,0)$ であり, 各子領域のX座標はleft と 等しい. 再帰的な処理により, その座標が更 新される.

\section{4 関連表示}

2.2節で, Mメソッド図では異なる空間にあ る領域どうしを直線または折れ線で結ぶこ とで関連性を示すと述べた. SVG画像の生成 により, 見やすい線を結ぶのは容易ではない ため, 本システムでは代わりに, マウスオー バーによって関連する領域の塗りつぶし色 を変更し，ハイライト表示するようにした．

\section{4 作図例}

図2に, 新学期に学生向けに話す内容に関 するMメソッド図を示す.これはコトづくり のデザインと言える.「学生証」にマウスカ ーソルを当てたとき, 離れた領域もハイライ ト表示されている.

\section{4 おわりに}

本稿では, 発想支援の効率化を目的として
開発した, Mメソッド図の描画システムにつ いて述べた. インデント化されたテキストデ 一タを用意し，プログラムを実行すれば，階 層や包含関係に基づいたMメソッド図を作 成できるようになった.

今後の課題には, 図の履歴管理や検索など の実装が挙げられる.

\section{参考文献}

[1] デザイン塾（監修）；松岡由幸（編著）； 氏家良樹; 浅沼尚 ; 高野修治 ; 伊豆裕一; 佐 藤浩一郎 ; 加藤健郎：「 $\mathrm{M}$ メソッドー多空間 のデザイン思考一」, 近代科学社, 160p., 2013. [2] 牧野茂一：「Mメソッド作図システムの 構築」, 和歌山大学システム工学部卒業論文, 2014.

[3] Murakawa, Takehiko; Nakagawa, Masaru: "Graphical Expression of SQL Statements using Clamshell Diagram", Journal of Japan Society of Information and Knowledge, Vol.19, No.2, pp.218-223, 2009.

[4] Murakawa, Takehiko; Nakagawa, Masaru: "Graphical Expression of SQL Statements Using Clamshell Diagram", IEICE TRANSACTIONS on Information and Systems, Vol.E93-D, No.4, pp.713-720, 2010.

[5] Murakawa, Takehiko; Nakagawa, Masaru: "Comprehension Support of SQL Statement using Double-Tree Structure", Proceedings of 3rd International Conference on Computer Supported Education (CSEDU 2011), Noordwijkerhout, The Netherlands, Vol.1, pp.318-323, 2011.

[6] Cross, Nigel (荒木光彦監訳, 別府俊幸, 高 橋栄訳）：「エンジニアリングデザイン 製 品設計のための考え方」, 培風館, 182p., 2008. 
表 1 文献[1]における M メソッド図の状況

\begin{tabular}{cccccc}
\hline デザイン対象 & アイウェア & ワークデスク & USB メモリ & ビークル & モビリティ \\
\hline 総ラベル数 & 53 & 45 & 54 & 53 & 30 \\
価値ラベル数 & 6 & 6 & 6 & 9 & 4 \\
意味ラベル数 & 17 & 14 & 12 & 13 & 5 \\
状態ラベル数 & 6 & 6 & 3 & 5 & 4 \\
属性ラベル数 & 17 & 15 & 23 & 19 & 8 \\
場ラベル数 & 7 & 4 & 10 & 7 & 9 \\
ラベル平均字数 & 3.55 & 4.09 & 3.72 & 4.06 & 7.83 \\
深さ & 5 & 5 & 5 & 5 & 4 \\
\hline
\end{tabular}

\begin{tabular}{|c|c|c|c|}
\hline 身分証明を大事に & 身を守る & 補傊制度がある & 人問関係を大切に \\
\hline 学生証 & 交通安全 & 奨学金 & 周囲と会話・相談 \\
\hline アカウント & 薬物 & 保険 & \multirow{2}{*}{$\begin{array}{c}\text { 自智・自殺・反社会的 } \\
\text { 行為に走らない }\end{array}$} \\
\hline 入䅦許可証 & & & \\
\hline
\end{tabular}

\begin{tabular}{|c|c|c|c|c|c|}
\hline よく読む & 相談先 & \multicolumn{2}{|c|}{ 通学 } & 家計急変時 & 大人の自覚をもって行動 \\
\hline 学生便筧 & 学生センター & \multicolumn{2}{|c|}{ 二輪注意 } & 祭急探用奖学金 & \multirow{2}{*}{$\begin{array}{l}\text { カンニングは } \\
\text { 学期の全単位剥奪 }\end{array}$} \\
\hline 㞛修手引 & 学科教員 & \multirow{2}{*}{$\begin{array}{l}\text { ブレーキなして } \\
\text { 坂を下りない }\end{array}$} & $\begin{array}{c}\text { 外周道路の } \\
\text { 走行禁止 }\end{array}$ & \multirow{3}{*}{$\frac{\text { 学部独自の援助金 }}{\text { 授業料免除 }}$} & \\
\hline & & & & & \multirow{2}{*}{$\begin{array}{c}\text { 刑事事件は } \\
\text { 身元が知れる }\end{array}$} \\
\hline 荡示物 & 子队刀リンセフー & \multicolumn{2}{|c|}{ 自動車通学は3年から要申請 } & & \\
\hline
\end{tabular}
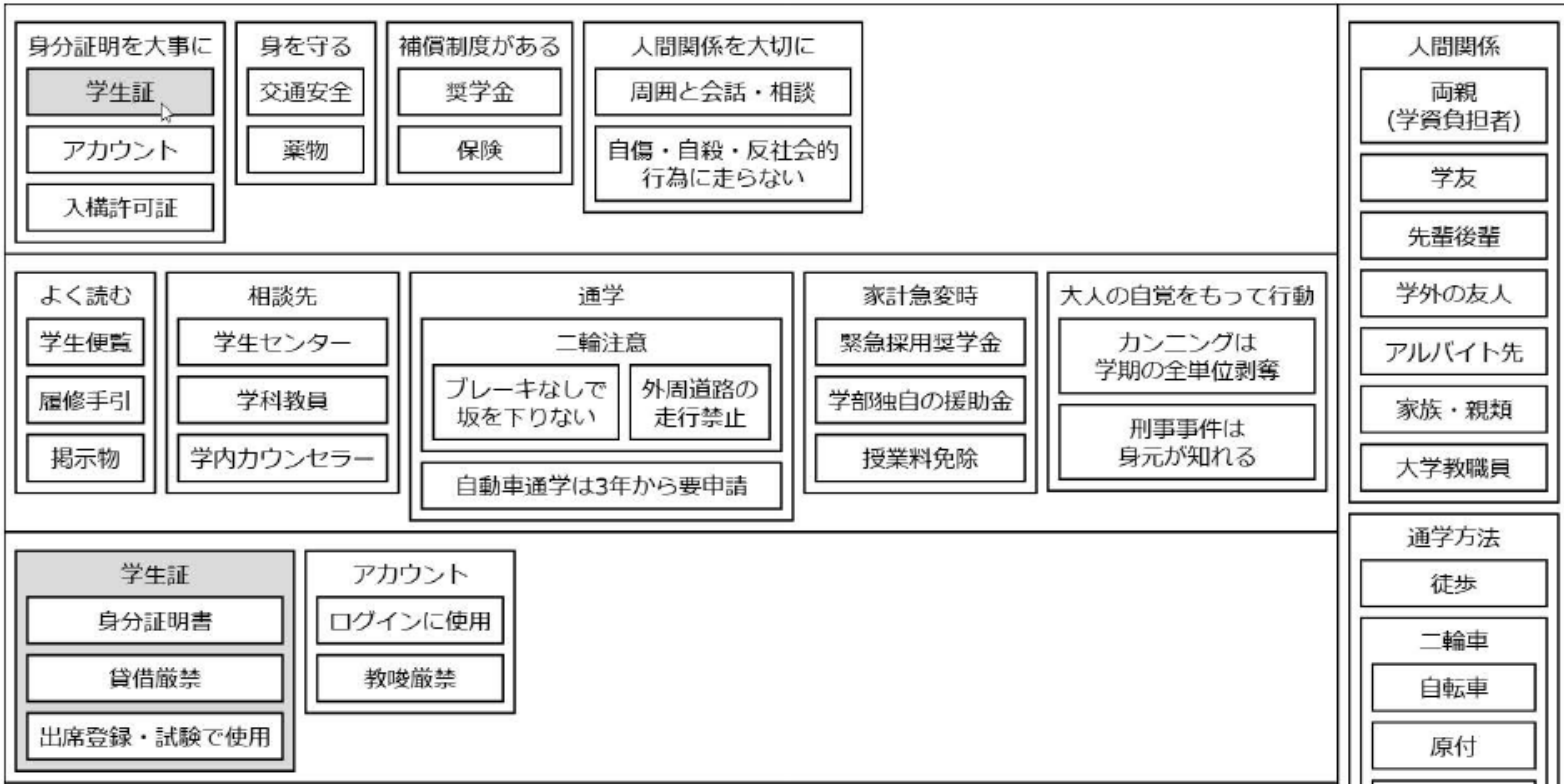

\begin{tabular}{|c|c|c|c|}
\hline 学内の対応 & アカウント & 保険 & 刑事事件 \\
\hline 学生センター & ユーザ名 & 学研多 & 暴行 \\
\hline 教務係 & パスワード & 学研賠 & 苆盗 \\
\hline 学科 & & & 薬物 \\
\hline 指導教員 & & & 交通事故・違反 \\
\hline
\end{tabular}

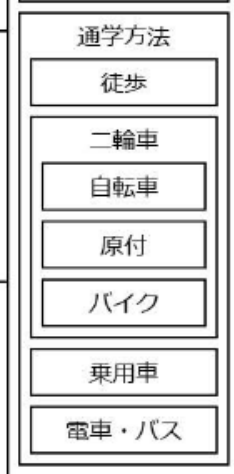

図 2 学生向けメッセージのデザインに関する $\mathrm{M}$ メソッド図 